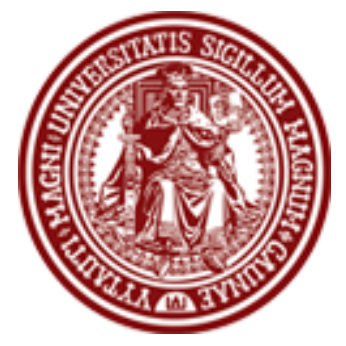

BALTIC JOURNAL OF LAW \& POLITICS

VOLUME 2, NUMBER 1 (2009)

ISSN 2029-0405

http://www.versita.com/science/law/bjlp

Cit.: Baltic Journal of Law \& Politics 2:1 (2009): 112-134

DOI: $10.2478 / \mathrm{v} 10076-009-0007-7$

\title{
MOTIVES IN SUPPORT OF JUDICIAL ACTIVISM: CRITIQUE AND ETHICS OF RESTRAINED ADJUDICATION AS AN ALTERNATIVE
}

\section{TOMAS BERKMANAS}

Associate Professor; Dr.

Vytautas Magnus University Faculty of Law (Lithuania)

\section{Contact information}

Address: S. Daukanto str. 28, LT-44246 Kaunas, Lithuania

Phone: 370-37-327873

E-mail address: t.berkmanas@tf.vdu.It

Received: June 30, 2009; reviews: 2; accepted: August 05, 2009.

\section{ABSTRACT}

The paper concentrates, from the critical perspective, on two general ideological themes used to support and welcome judicial activism mainly in the jurisprudence of the highest level courts of the United States and Lithuania. This task is relevant in light of the judicial activism spreading in court practices, as well as its clear embrace in the academic community of Lithuania.

The first theme focuses on the practice and ideology of Justice John Marshall. It is rather evident that the Marshallian ideas and activities form an ideological basis for an active and politically powerful constitutional court. However, due regard should be paid to the critique of the Marshallian heritage.

The other theme is built on the juxtaposition of reality and the law as text, the former being much more complicated. This allegedly supports the theses either that adjudication could not avoid taking the form of precedent (the creation of law rather than the interpretation of law), or that judicial interpretation is meant to fill the gaps or fix inconsistencies in the legal text (the so-called thesis of interpretative sufficiency). However, 
due regard should be paid to the consequences of the realization of both theses to the political framework of the state.

This article attempts to fill in these aforementioned gaps in critical attention with compensatory critique, as well as to suggest an alternative approach to the propaganda of judicial activism - an ethics of restrained adjudication.

\section{KEYWORDS}

Judicial activism, legal interpretation, Justice John Marshall, political framework of the state, restrained adjudication 


\section{INTRODUCTION}

In the five years following the publication of an article on the problem of judicial activism and related issues, ${ }^{1}$ the situation in Lithuania has changed in two directions. Firstly, we witnessed a clear rise of academic interest in the problems connected to legal interpretation, while issues related to judicial activism were also being touched upon in one or another form. ${ }^{2}$ Secondly, the critical opinion in relationship to judicial activism acquired more or less discernable contours. ${ }^{3}$

1 Tomas Berkmanas, "Teismo aktyvumo kuriant ir aiškinant teisę plètros tencencija, motyvai ir problemos" (Tendency, Motives and Issues of the Expansion of Judicial Activism in the Creation and Interpretation of Law), Teisès problemos 2 (44) (2004).

2 These articles could be mentioned: Remigijus Šimašius, "Teisès aiškinimas ir jo privalomumas" (On Mandatory Interpretation of Law), Teisès problemos 2 (44) (2004); Kęstutis Jankauskas, "Adekvatus teisès principu aiškinimas konstitucinejje jurisprudencijoje" (Adequate Interpretation of Legal Principles in Constitutional Jurisprudence), Teisès problemos 4 (46) (2004); Giedrè Lastauskienè, "Teisinio teksto interpretavimo ribu ir teisès principu santykis: teorinès nuostatos ir Lietuvos teismu praktika" (Relationship between the Limits of the Interpretation of the Legal Text and the Legal Principles: Theoretical Approaches and Practice of Lithuanian Courts), Teisés problemos 1 (47) (2005); Giedre Lastauskienè, "Teisinio teksto tyrimo metodologija: teisès normu nustatymas" (The Methodology of the Investigation of the Legal Text: Identification of Legal Norms), Teise 56 (2005); Egidijus Jarašiūnas, "Konstitucine justicija ir demokratija: keletas saveikos problemu" (Constitutional Justice and Democracy: Some Problems of Interaction), Jurisprudencija 64 (56) (2005); Vytautas Sinkevičius, "Konstitucijos interpretavimo principai ir ribos" (The Principles and Limits of Interpretation of Constituion), Jurisprudencija 67 (59) (2005); Alfonsas Vaišvila, "Teisès aiškinimas kaip teisès atpažinimas istatymu tekstuose" (Legal Interpretation as Identification of Law in the Texts of Statutes), Jurisprudencija 8 (86) (2006); Ernestas Spruogis, "Teisès aiškinimo probleminiai aspektai" (Problemic Aspects of Legal Interpretation), Jurisprudencija 8 (86) (2006); Giedrè Lastauskienè, "Turiningasis teisinio teksto aiškinimas - panaceja ar pavojus?" (The Thoughtful Disquisition of Legal Text - Panacea or Risk?), Jurisprudencija 8 (86) (2006); Egidijus Kūris, "Konstitucija kaip teisè be spragu" (The Constitution as Law without Gaps), Jurisprudencija 12 (90) (2006); Egidijus Šileikis, "Aktyvistinè konstitucinè justicija kaip subtili diskecija inspiruoti teisinius modelius" (Active Constitutional Jurisprudence as a Method to Influence Legal Issues), Jurisprudencija 12 (90) (2006); Rytis Jokubauskas, "Teisminio precedento privalomumo problema Lietuvos teisineje sistemoje" (The Problem of Obligation of Judicial Precedent in the Lithuanian Legal System), Jurisprudencija 5 (95) (2007); Gediminas Mesonis, "Kai kurie Konstitucijos interpretavimo aspektai: expressis verbis ribos (Some Aspects of Interpretation of the Constitution: the Limits of the Expressis Verbis)," Jurisprudencija 5 (107) (2008); Egidijus Jarašiūnas, "Oficialios konstitucinès doktrinos koregavimo problemos (The Problems of Correction of the Official Constitutional Doctrine)," Jurisprudencija 1 (115) (2009); Gediminas Mesonis, "Keli konstitucijos interpretavimo askeptai: vertybiniu (moraliniu) argument galimybe ir ribos (Some Aspects of the Interpretation of the Constitution: the Possibility and Limits of Valuable (Moral) Arguments)," Jurisprudencija 2 (116) (2009); Dangutè Ambrasienè and Solveiga Cirtautienè, "Teismo precedento reikšme Lietuvos teismy praktikoje (The Role of Judicial Precedent in the Court Practice of Lithuania)," Jurisprudencija 2 (116) (2009); Valentinas Mikelènas, "Interpretacinis žaismas, arba kaip kurti teisę be parlamento (Interpretation Game or How to Make Law without Parliament)," Jurisprudencija 2 (116) (2009); Egidijus Kūris, "Teismo precedentas kaip teisès šaltinis Lietuvoje: oficiali konstitucinè doktrina, teisinio masstymo stereotipai ir kontrargumentai (Judicial Precedent as a Source of Law in Lithuania: the Official Constitutional Doctrine, Stereotypes of Legal Thinking and Counter-arguments), "Jurisprudencija 2 (116) (2009).

${ }^{3}$ It should be noted that some scholars that for some time were quite firmly in the camp of pro-activists recently have started to take a more cautious approach. For example, Egidijus Jarašiūnas in his recent article alleges that "correction of [constitutional] jurisprudence is only an exception," there should be no place for arbitrary deviations, and the way should be "shut for such legal creativity, which leads to the anomaly, disrupting the constitutional system" (Egidijus Jarašiūnas, "The Problems of Correction of the Official Constitutional Doctrine," supra note 2: 54); Valentinas Mikelenas, who formely holded that judicial interpretation should be socially balanced and adjusting law to the changed social realities (Dalia Mikelènienè and Valentinas Mikelènas, Teismo procesas: teisès aiškinimo ir taikymo aspektai (Judicial Process: Aspects of Legal Interpretation and Application of Law) (Vilnius: Justitia, 1999), p. 143-147), in his recent article conculdes that "distrust in [Lithuanian] courts is partly caused by their over-activeness, inconsistent practice, ignorance of the rules of interpretation" (Valentinas Mikelenas, "Interpretation Game or How to Make Law without Parliament", supra note 2: 89). 
On the other hand, this critical discourse is still in the necessity of advancement, and not only because there are still critical arguments to articulate, or because the pro-activist academic position is still overwhelming. Today no one doubts that not only American, but also Lithuanian constitutional jurisprudence has undergone a period of judicial activism (especially in the period from 2002 to 2008), confirming the thoughts of Antionio Gramsci, here relied on by David Dyzenhaus: "theory and practice are linked ... because success at the theoretical level, while in no way sufficient condition for influencing or sustaining the practice, is necessary condition. ${ }^{\prime 4}$ In some respects the other part of the thought "inadequate reflection will eventually issue in inadequate practice" ${ }^{5}$ - is also valid here. As will be demonstrated in the article, the practice, if pro-activist, could be considered inadequate as related to the ethics required from the conduct of the judge. Accordingly, exactly this Lithuanian context reaffirms and necessitates the furtherance of the critique of judicial activism. Judicial activism has clearly stepped out from the classrooms of academic institutions into the court halls and started influencing the lives of all in Lithuania. Courts started "playing kings", although kings, in our contemporary political framework, they were not supposed to be; or, at least, they should, in all possible ways, avoid this mighty playground.

This paper is a continuation of the ideas and analysis of the aforementioned article of 2004. The object of the research in this paper is to expose certain motives in favour of the expansion of judicial activism that were not touched upon enough or demanded greater and more rigorous articulation in the aforementioned article. These motives, generally, are two - the support of judicial activism by using the ideas and activities of Justice John Marshall (Part 1), and the support of judicial activism by the idea of the complexity of reality in relationship to law as text (Part 2 ). The second motive is thoroughly investigated by touching upon the concepts of official constitutional doctrine, legal precedent and gaps (lacunae) or inconsistencies of law, estimating the impact of judicial activism to the political framework of the state. Finally, this article suggests an alternative approach to the pro-activist position - the ethics of restrained adjudication - albeit predominantly in general terms (Part 3).

\section{THE MARSHALLIAN CONTROVERSIES}

One of the major ideological themes in support of judicial activism in Lithuania could be titled "the ideas and activities of Justice John Marshall". Therein Justice

\footnotetext{
${ }^{4}$ David Dyzenhaus, Legality and Legitimacy: Carl Schmitt, Hans Kelsen and Hermann Heller in Weimar (Oxford: Oxford University Press, 2003), p. 5.

${ }^{5}$ Ibid.
} 
John Marshall is presented as a founder of the constitutional review (with the consequence of the invalidation of law, if it contradicts the Constitution) as an immanent part of the powers of the court institutionally involved in constitutional adjudication, thus making it an active and politically powerful institution. Rather frequently this support results in a mere hiding under the authority of Marshall, without any deeper inquiry into his heritage. Nevertheless, such an approach reveals only "one side of the coin", as the critique of the Marshallian ideas and activities is far from unnoticeable. Thus, some aspects of the "other side of the coin", especially as generally relevant, should be revealed.

Much of Marshall's ideology is concentrated in two very well known cases Marbury and McCullock - which are thoroughly analyzed not only by American scholars, but all over the world. Here we focus on the fragment of a well-known paper by Sanford Levinson titled "Law as Literature". Contemplating the importance of the writtenness of the US constitution, Levinson directs his thoughts to Marshall's ideas in Marbury, where Marshall writes as follows:

\begin{abstract}
"the powers of the legislature are defined and limited; and that those limits may not be mistaken, or forgotten, the constitution is written"; then Marshall goes on to say, "To what purpose are powers limited, and to what purpose is that limitation committed to writing, if these limits may, at any time, be passed by those intended to be restrained". Marshall, however, [as Levinson asserts,] undercut his argument in Marbury when he decided McCulloch v. Maryland ... . So far are words from having obvious meanings that Marshall reminds us that "such is the character of human language, that no word conveys to the mind, in all situations one single definite idea; and nothing is more common than to use words in a figurative sense" ... . And the "writtenness" of the Constitution becomes a far more complicated issue once one supplements the textualism of Marbury with the "texturalism" of McCulloch. ... . [Levinson concludes that] the very multiplicity (if not promiscuity) of Marshall's approaches to constitutional interpretation ... calls into question whether interpretation for Marshall (or for anyone else) ever transcended a desire to achieve specific political results." ${ }^{6}$ (italics - T. B.)
\end{abstract}

What we could learn from these observations by Levinson? First of all, the Marshallian foundations of the judicial power of the constitutional review are fundamentally textualistic - an argument in Marbury is the argument about the supremacy of the written text of the constitution over the texts of other written laws. Therefore, if this is the argument on which this power is based at the most fundamental level, then the textualistic approach itself should be the basic approach of the court making the constitutional review - that is the approach it is

\footnotetext{
${ }^{6}$ Sanford Levinson, "Law as Literature," Texas Law Review No. 3, Vol. 60 (1982): 374-375.
} 
founded on. And if we perceive the Marshallian foundations of constitutional review as an authoritative example, we shall also adopt the inherent textualism therein.

The second aspect is related to the inconsistency of Marshall's approaches while comparing Marbury and McCullock. Their comparison generates a suspicion that perhaps all the Marshallian process of the consolidation of the powers of the court is a political process (therefore, not theoretical, not based on the text of American Constitution or some nature of general constitutional process). On the other hand, as history proves, probably any legal system should undergo its Marshallian stage of development. We could even agree on the thesis that this stage (as undergone) should be the characteristic trait of every modern and developed legal system, and former Chief Justice of the Constitutional Court Egidijus Kūris could be held in esteem for being the "Marshall" of the Lithuanian legal system.

However, we should also always bear in mind that at least some American scholars hold to the opinion that Marshall "is, perhaps, the great Nietzschean judge of our tradition", putting the constitutional "text into a shape which will serve his own purpose" ${ }^{\prime 7}$. And when Egidijus Kūris, reacting to Petras Ragauskas's antiactivist and anti-interpretativist position, ${ }^{8}$ alleges that, "starting from the era of Marbury v. Madison, constitutional justice has been developing into a different direction" ${ }^{\prime \prime}$, we should also have in mind that the development in this direction was the result of a political rather than a judicial process.

\section{THE CHALLENGE OF REALITY TO THE LEGAL TEXT}

As it has already been mentioned, even Marbury's ideology may support an anti-activist position due to textualism, which this case (even as a representation of a political process) is fundamentally based on. However, this kind of textualism could be criticized by different rationale, which belongs to the second general statement to which we must respond. The reasoning proceeds as follows: the reality or, otherwise, law at the behaviorist level is always much more complicated than the legal norms or, otherwise, law at the normative/textual level, and this is even more valid to the constitutional text which has the characteristic traits of ambiguity, vagueness, gaps of law and the like; therefore, court jurisprudence, and especially constitutional jurisprudence, could not avoid taking the form of precedent, the creation of law rather than interpretation of law. Or, it could be

7 Ibid.: 385 (citing Richard Rorty's text "Nineteenth-Century Idealism and Twentieth-Century Textualism," in Consequences of Pragmatism 139 (1982)), 389.

${ }^{8}$ Generally see Petras Ragauskas, "Konstitucinio teismo vaidmuo istatymu leidyboje (The Role of the Constitutional Court in the Process of Legislation)," Teisés problemos 1 (43) (2004).

${ }^{9}$ Egidijus Kūris, "Konstitucinis Teismas ir istatymu leidyba: žvilgsnis "iš vidaus" (Constitutional Court and Legislation: View from "the Inside")," Teisès problemos 1 (43) (2004): 120. 
alleged, that, because of the supremacy of the constitution, interpretation of the constitutional court (so-called official constitutional doctrine) is meant to fill the gaps of the supreme law or fix its inconsistencies, being the so-called thesis of the interpretative self-sufficiency of constitution.

\subsection{COURTS OFFICIALLY "PLAYING KINGS"}

We could start from a rather odd reaction to this "reality" problem, showing how initially a real problem and disadvantage could be transformed into the advantage in the process of consolidation of the judicial political powers. At first glance this problem is very impractical to the initial project of the implementation of the rule of law by such a politically neutral institution as a court. The discrepancy between reality and law as text, as simple as it is, means that courts are confronted with the linguistic interpretative/creative continuum without any clear or sufficient guidance where and how to end it, when the authority of making the end to this process should come not from men, but from law (if we are talking about the rule of law, but not the rule of men). But then some part of this argumentation is accepted and even with an emphasis - yes, we are confronted with this linguistic interpretative/creative continuum, and afterwards it is rather rhetorically alleged that it must be somehow ended, we are in the necessity of the finitude of interpretation/creation, and the end should be made in or by some institution, i.e. the interpretation/creation of some institution should be finite. This institution is the court. As related to constitutional jurisprudence, this notion in Lithuania has the form or name of the "official constitutional doctrine".

First of all, it should be noted that no one questions the institutional supremacy of the interpretation (even if it takes the clear form of the creation of what is not written in the text of constitution) of the constitution made by the constitutional court, if we understand it as some very technical aspect of the political framework of the state. Exactly in the same way we have the notion of the un-questionability of the parliament's acts - no one can allege in court that we do not abide by some specific parliament act because we do not agree to it; whether we agree or not, we have to abide by it. And whether we agree to some decisions of the constitutional court or not, we have to abide by them and that could be the meaning of the "officiality" of the "official constitutional doctrine". But we can not only criticize one or another decision of the constitutional court at the academic level, as Kūris points out; ${ }^{10}$ we can also inquire what some constitutional doctrine, taken as a generalization of the case-law of one or another period, means at the

${ }^{10}$ Ibid. : 122. 
level of political theory and what impact it has to the political framework of the state.

Not inquiring much into the problem of the intersection between the interpretation and creation of law at the moment, we should definitely accept the rather obvious thesis that courts sometimes create law, and the higher the instance of the court, the more this sometimes transforms into often. In this respect two critical ideological themes - one more historical/practical, the other more theoretical - are developed by the anti-activists.

The first theme focuses on the differences in the articulation and the conception of the judicial creation of law in two major, historically formed legal traditions. The common-law tradition is usually presented as the tradition of judicial precedents - the norms of law, created by courts; and therein the judicial creation of law is much more coherently accepted, differently from the civil-law tradition. Therefore, when legal scholars are confronted with the attempts to introduce "more judicial precedent" into the Lithuanian legal system, one of the arguments against this tendency is that it does not correspond to the civil-law tradition, which our country belongs to. ${ }^{11}$ This argumentation, as based on the authority of the tradition and, therefore, as any only-based-on-authority argument, does not confirm the anti-activist position (which concerns the judicial creation of law as an ultimate form of the judicial activism) in the same ways as the other theoretical argumentation.

To be certain, it would not be right to allege that the civil-law tradition is void of precedent-based adjudication. Firstly, it is very well known (and this knowledge is used in the pro-activist camp) that both traditions in the contemporary world are in the stage of convergence. The civil-law tradition is really in the necessity of "rethinking of the role of precedent" in front of the parliamentary legislation which usually lacks coherency, clarity, conceptual and terminological consistency, thus inevitably throwing judges into an interpretative turmoil with a leading suspicion that it sucks them into the domain of political activity. ${ }^{12}$

Secondly, we should clearly differentiate between the two aspects/characteristics of what we may call precedent-process in the common-law tradition: (1) creation of a precedent and (2) following a precedent (or stare decisis in the exact meaning of this phrase). This second characteristic is definitely not alien to the civil-law tradition, because it is not only that tradition makes or could make a judge to follow/consult the previous decision, but a simple convenience and

\footnotetext{
${ }^{11}$ For example, see Dangutè Ambrasienè and Solveiga Cirtautienè, "The Role of Judicial Precedent in the Court Practice of Lithuania," supra note 2: 73-74.

12 Mary Ann Glendon, "Comment": 100-103; in: Antonin Scalia, A Matter of Interpretation: Federal Courts and the Law (Princeton, New Jersey: Princeton University Press, 1997).
} 
even common/natural sense. Of course, there is a rather crucial difference between being a binding decision (in other words, official precedent) and being a decision only to consult (we could call it a practical precedent); however, that which concerns the latter mode of the precedent-based adjudication is that both traditions in one or another form (more or less explicit) contain that. And even the commonlaw tradition, especially with a wider historical scope in mind, is more firmly based on a practical than on an official precedent conception. Until now there is a known and accepted conception that "whether a decision becomes an influential precedent depends on the wisdom of the decision and the rhetorical elegance of the opinions supporting the decision", and "if a case deviates from traditional principles of law, it will be quickly forgotten". ${ }^{13}$ The understanding of the legal precedent as something strictly obligatory to courts (strict stare decisis), as a real declaration of law - i.e. positivistic approach to legal precedent - is much more the product of modernity, especially starting from the $19^{\text {th }}$ century. ${ }^{14}$ On the other hand, not inquiring more into the historical details, exactly this second characteristic of the precedent-based common-law tradition - stare decisis itself - is much more useful for the antiactivists than for the pro-activists; being a positivistic feature of the common-law tradition, it is about restraining judges, but not over-empowering them. In this respect, stare decisis is really of those good common-law habits in the anti-activist sense, and should be attended to by the anti-activists when this habit loses vigor. ${ }^{15}$

To summarize this first ideological theme developed by anti-activists (i.e. emphasis on the traditional divergences): even if this argumentation is used in the anti-activist camp in the civil-law countries, including Lithuania, its weaknesses should be born in mind, as well as the fact that not everything from the commonlaw tradition is impractical and unhelpful for the anti-activists.

Starting the second theme developed by the anti-activists, we should turn back to the two previously mentioned characteristics of the precedent-process, and now to the first characteristic - the creation of the precedent, which is, in other words, the judicial creation of law. The second theme focuses on this aspect of the judicial world (generally or as a characteristic trait of the common-law tradition), and is developed on a much more theoretical level than the first theme (although

13 George P. Fletcher, Basic Concepts of Legal Thought (New York, Oxford: Oxford University Press, 1996), p. 69. This condition of precedent, apparently inherited from the pre-modernity, in fact, could be detrimental to strict stare decisis, because it does not require all precedents to be followed, but only those, which have certain conditions.

${ }^{14}$ Ibid., p. 63 ("In the more conventional Anglo-American view of stare decisis, as it emerged in the nineteenth century, the courts declare what the law is. And because their decisions are the law, they constitute precedents binding on judges and litigant who come after"); p. 69-70 ("In the last two hundred years there has been a movement in Anglo-American law to make case law more like statutory law. In the mid-eighteen century, in the writings of Blackstone, judicial decisions are treated as evidence of the law, not as the law itself. ... The English positivist movement of the nineteenth century generated the idea that judicial decisions were not just evidence of the law, but conclusive on the law. Thus emerged the idea of stare decisis - the principle that precedents must be followed as binding law.").

${ }_{15}$ Mary Ann Glendon, supra note 12: 110. 
still clearly historically determinate, as the theory has its origins in the Enlightenment project). The main thesis is that the creation of law by courts contradicts the principles of democracy and the separation of powers. This argument is one of the major themes relied upon by the anti-activists, and probably even more by the common-law tradition representatives, as therein this contradiction is much more obvious. Here we would like to emphasize only one aspect of this theme.

In the United States it has already been observed for a long time that their political system has substantial traits of aristocratism as reflected in the activity of the courts. Judges are not democratically elected, they are appointed based on the principles and requirements of professionalism, which usually are under their own control, making lawyers similar to the closed-guild of some craftsman carefully guarding "the gates" of their profession. ${ }^{16}$ Therefore, if judges create law, the political framework of the state entails a substantial element of what we may call "professional aristocracy", or, figuratively speaking, courts then "play kings". ${ }^{17}$ This aspect of the judicial precedent (as the creation of law, not its following) should be always kept in mind. Accordingly, the Lithuanian system should also acquire a substantial element of the other - aristocratic - form of the government and become a rather clear hybrid of the democratic and aristocratic form of political rule, if judicial precedent as the element of the legal system would be explicitly accepted. And it is not some poetic metaphor, not some speaking about "the aristocrats of mantle", but a rather theoretical statement, which is especially valid to the constitutional adjudication. To reiterate Antonin Scalia's and Mary Ann Glendon's emphasis, "the Constitution is ... a design for government which places important limits on ... judicial ... lawmaking. ... the [US Supreme] Court's freewheeling approach to constitutional interpretation is a far more serious matter than its careless ways with statutes. For as judicial law-making expands, the democratic elements in our republican experiment atrophy." ${ }^{18}$ We could only add that the Lithuanian republican experiment is the one which design contains this rule as the first article of the Constitution: "The State of Lithuania shall be an

\footnotetext{
${ }^{16}$ A notorious example on this aspect in Lithuania is the Ruling of the Constitutional Court of the $20^{\text {th }}$ of February, 2008 (generally see On the Qualification Requirements of Higher Education in Law for the Persons Who Wish to Hold, under Procedure Established by Laws, the Position of a Judge, Ruling of the Constitutional Court of the Republic of Lithuania, Official Gazette (2008, no. 23-852)), where the Court quite obviously involved in a rather creative activity while speaking on the spheres far beyond those covered by the petition.

${ }^{17}$ Antonin Scalia, "Common-Law Courts in a Civil-Law System: The Role of United States Federal Courts in Interpreting the Constitution and Laws": 7; in: A Matter of Interpretation: Federal Courts and the Law (Princeton, New Jersey: Princeton University Press, 1998). In this respect Scalia takes a rather radical anti-activist approach, by alleging that although "common law should [not] be scraped away as a barnacle on the hull of democracy," nevertheless, he is "content to leave the common law, and the process of developing the common law, where it is", and go on essentially without it, as "we live in an age of legislation, and most new law is statutory law" (ibid.: 12, 13).

18 Mary Ann Glendon, supra note 12: 108-109.
} 
independent democratic republic" (italics - T.B.). That is unparalleled in the republican experiment of the US.

\section{2. "DISAPPEARING" GAPS AND INCONSISTENCIES OF LAW}

By a slight change of wording (from creation to interpretation of law), there is some other ideological sub-theme used to support the judicial activism, now mainly in the realm of the constitutional jurisprudence. This is the thesis of interpretative self-sufficiency of the constitution. ${ }^{19}$ It is mainly based on the Kelsenian "pyramidal" ideology ${ }^{20}$ and formulated as follows: as constitution is at the top of the pyramid of the legal norms, there should be no gaps and inconsistencies in the constitution, because otherwise it could not be the highest legal act, and some other act - as filling the gap or solving the inconsistency - would become higher than the constitution or at least at the same level as the constitution. In order for this not to happen, the constitutional court should intervene with its official constitutional doctrine thus filling in the gaps and solving the inconsistencies. It even leads to the allegation that, therefore, constitutions have no gaps and inconsistencies at all. ${ }^{21}$

Nevertheless, this thesis is based on the conception and, highly probably, misconception of a very complicated aspect of the Kelsenian theory. First of all, at the top of the pyramid is not the constitution in a regular sense, but Grundnorm - a very complicated concept from Kelsenian theory. Grundnorm is the norm of an act, which gives/provides the authority to create law; basically it is the norm of this one act $^{22}$ it is the norm that this act of granting/recognizing of authority is happening, and, as some authors would say, that really wipes off the boundaries between the spheres of law and politics. ${ }^{23}$ On the other hand, the norms of the Kelsenian pyramid, if we start not from Grundnorm but from the regular constitution and so on down to the bottom, do not spring out of nothing, as some self appearing phenomena. Therefore, what or maybe even who is at the top of the pyramid? That is the problem of sovereignty, which was, according to Schmitt, negated by Kelsen, and that was achieved precisely by the conception of Grundnorm. ${ }^{24}$ But if we

\footnotetext{
19 For example, see Gediminas Mesonis, "Some Aspects of the Interpretation of the Constitution: the Possibility and Limits of Valuable (Moral) Arguments," supra note 2: 47.

20 The similarity of the Kelsenian system of norms to a pyramid is an architectural-spatial metaphor that should only help to understand the theory; there are no norms "above/higher than" other norms in exact sense of words, Kelsen himself puts word higher than in quotation marks (Hans Kelsen, Grynoji teisés teorija (Pure Theory of Law) (Vilnius: ALK, Eugrimas, 2002), p. 47).

${ }^{21}$ For the exposition of this or the like approach in the Lithuanian academic thought, generally see Egidijus Kūris, "The Constitution as Law without Gaps," supra note 2.

${ }^{22}$ Hans Kelsen, supra note 20, p. 174.

${ }^{23}$ That is why there is some proximity between the positivist position and a rather nihilist one (i.e. that of the political holism), stating that "the law is merely the product of communities powerful enough to have their preferred meaning imposed as the law" (David Dyzenhaus, supra note 4, p. 8).

${ }^{24}$ Carl Schmitt, Political Theology: Four Chapters on the Concept of Sovereignty (Chicago and London: The University of Chicago Press, 2005), p. 18-21.
} 
logically continued the pyramid beyond Grundnorm and accepted the fundamentals of the contemporary political frameworks, then at the top we would find simply people (or, more generally, humanity) as a sovereign. That is in relation to what any contemporary legal system, any contemporary political framework in its entirety is positioned. Humanity is either the ultimate authority to law (as people) or it is the central value (as human) of any contemporary legal system, which, in this way, may be called humanistic. And all that is also the heritage of anthropocentric beginnings/projects of Enlightenment. We may discern two aspects of this humanism of the project - one as related to people and solved by the mechanism of democracy, and one as related to human and solved by the liberalism and the protection of human rights.

This correction of the stereotypical adaptation of Kelsen's theory should be the starting point when we deal with the problem of the gaps and inconsistencies in constitutions and even in any laws. It is not that the regular constitution is at the top of the legal system; even Kelsen would not agree with that. Therefore, if confronted with legal gaps and inconsistencies, judges should first consider their institutional role as that in the political framework positioned to the aforementioned central humanistic value. They should consider and balance their democratic and liberalistic roles and then accept the corresponding inner points of view. Their democratic role is definitely not to create law; that authority is not given to them. Law, as much as possible, shall be created by the people or their representatives. The democratic role of judges is to apply that will of the people, and if that will is missing, and especially if it was exactly the will to make it missing - then they should restrain from intervention. That is not some scientific/absolute rule - it should be the part of the exactly internal point of view, of the ethics of judges. And even this ethics should leave intact the relationship to their liberalistic role - to protect humans from the possible extreme atrocities of the people by the help of the system of the human rights protection. Even this role, as a matter of logics, makes no impact on the ethics of restrained adjudication. ${ }^{25}$

25 See Part 3. Supplementing the thesis, lawyers know well two general legal principles, which are directly related to the gaps of law, as they provide the general guidelines of judicial action in their case (1) "what is not allowed by regulation, that is forbidden," (characteristic to the criminal/administrative law, but not entire public law), and (2) "what is not forbidden/regulated, that is allowed," (characteristic to the private law). Which principle should be valid in the case of the constitutional law? The understanding of liberalistic and humanistic foundations of the contemporary political frameworks would indicate for the priority of the second principle, which exactly points to the non-intervention of courts in the case of gaps of law/non-regulation. On the hand, "constitution without gaps" approach points to the priority of the first principle, as in the case of this principle court always has to intervene; theoretically in this case there are no legal gaps, no activity is such in relationship to which law does not function as a matter of power. Therefore, such approach could be considered as an indication of the Soviet inertia, as reflected in the corresponding hierarchical and totality-of-regulation-centered modes of thinking, when there should be no free zone in relationship to law, the latter being understood as a substratum of power, but not the foundation for the common-wealth, for the res publica, what also includes the liberation of a human, the making of some private/free zone, which is out of the reach of political-legal powers. 
Nevertheless, constitutions definitely do not regulate all aspects of our life; they have gaps, deliberate or not. To allege that any lower legal act should be evaluable in relationship to the constitution in order for it to preserve its status of the highest law and that, therefore, constitutions do not or shall not have gaps, which are filled by the official constitutional doctrine, does not make any sense. Because, as simple as it is, it is not so (i.e. they have gaps), and there is no clear theory that would require this institutional (having in mind courts) and powerusurping appropriation. At least, which norm is higher is not at issue; rather, the questions are what the people's will is, and whether every human is protected from the possible extreme atrocities caused by this will? If some issue becomes very important to the people, they will make appropriate changes or additions to constitutions or other legal norms by the appropriate procedure; if they do not do that, then it is exactly their will not to do that, and it is not for the court to supplement that will. The only exception is the aforementioned atrocities caused by the will (or its absence) of the people (especially if done at the level of constitution), but, generally, it should be extremely exceptional case. In relationship to this we could note that the "door" to the field of politics for courts could lie at the intersection between so-called inscribed and universal human rights (or the universally accepted infringements of human rights), if they diverge. It would be probably hard to negate that most constitutions today inscribe universal human rights sufficiently, this way shutting this door. Thus, guarding human rights corresponds to sticking to the text of constitution, and if it has a gap that does not lead to the universally accepted infringement of a human right, it should be left as it is. ${ }^{26}$

Before starting the articulation of the conception of the ethics of restrained adjudication, we would like to illustrate by one concrete example how the ideology and academic-political pressure of the necessity of "filling the gaps" by courts was applied in Lithuania (which relates to the jurisprudence of the Supreme Court) together with the leading contradictions. At least until 2005 the jurisprudence of the Lithuanian courts was unclear and ambiguous in relationship to whether the doctrine of restrictive or absolute state immunity should be applied in civil procedure/adjudication. The old Code of Civil Procedure, inherited from the Soviet tradition, which was functioning until the end of 2002, was quite clear on this matter - the doctrine of absolute state immunity should be applied. The new Code of Civil Procedure, which came into force on the $1^{\text {st }}$ of January, 2003, was silent on

\footnotetext{
${ }^{26}$ We could only suggest in this respect that if any major Western country has some different regulation from some allegedly universal regulation (as human right or in relation to human right), the test of universality should fail. This concerns, for example, the death penalty. Lithuanian Constitution is essentially silent about the death penalty, and there is no universal acceptance that this gap infringes the human right to life (the example could be the US).
} 
this matter. However, the pressure on this absolute immunity approach, motivated by the out-datedness and incompatibility of this doctrine with changed historical circumstances, ${ }^{27}$ was growing almost throughout the period of regained independence. The Lithuanian courts, led by the Supreme Court, therefore, started to deviate from the doctrine of absolute immunity (beginning from $Y$. Stukonis $v$. USA Embassy case); however, with rather clear reluctance in doing that and, therefore, with proliferation of ambiguities in this matter. The result was sticking to the so-called modified doctrine of absolute state immunity. ${ }^{28}$

Regretting such a situation, two scholars - Andrius Smaliukas and Yvonne Goldammer - made this remarkably contradictory conclusion:

We can only hope that the Lithuanian Supreme Court in the future will succeed to demarcate itself from the political tensions and perform the real jurisdictional legislative function, which, in the absence of the legal enactments, is necessary in the present situation. ${ }^{29}$ (italics - T.B.)

It is a rather simple contradiction to say that the Court should legislate by demarcating itself from the political tension: it is a political action to legislate on this matter. On the other hand, the position of the aforementioned authors of how the gap ${ }^{30}$ should be filled is clear: restrictive doctrine should be chosen, and accordingly, authors are clearly doctrinally partial. As known, the borderline between academic and political pressures is not always clear. They rather seldom intermingle, and that is an especially characteristic trait of the world of lawyers and its spheres of education and profession. ${ }^{31}$ Therefore, who could negate that the hope, and probably also the will, of the authors was not part of the same political (or, generally, outside) tension from which the Court should demarcate itself? The Court was pressed to adopt the restrictive doctrine of state immunity. On the other hand, statutory law was either explicitly in favor of the other - absolute immunity doctrine (i.e. the old Code) or was silent on the matter (i.e. the new Code).

\footnotetext{
27 Therefore, this example also points to the problematic aspect of the dynamic legal interpretation, i.e. when law starts contradicting to the so-called contemporary requirements/values of the society or, in other words, historical realties. If there is a gap of law, it is, in this case, formed by this process.

${ }^{28}$ Generally see Andrius Smaliukas and Yvonne Goldammer, "The Restrictive Theory of State Immunity in Lithuania: Reality or Illusion," Baltic Yearbook of International Law 5 (2005).

${ }^{29}$ Ibid.: 132.

${ }^{30}$ In 2005 it was unambiguously the gap, as the new Code was silent on the matter; the situation as related to the old Code could be considered as the one when law is historically out-dated.

${ }^{31}$ First of all, the aspect of the legal profession as the closed-guild, carefully guarding "the gates" of their profession, should be mentioned (also supra note 16). Secondly, in this concrete case the role of the professor Valentinas Mikelenas, who at the relevant time was also the judge of the Supreme Court of the Republic of Lithuania, is exemplary. As observed by Smaliukas and Goldammer, Mikelenas "in 1999 wrote that in the $y$. Stukonis $v$. USA Embassy case the Lithuanian Supreme Court, after having analyzed the historical aspects of the enactment of CCP Article 479, concluded that the application of the absolute State immunity principle is incompatible with the completely changed historical circumstances, thus the principle of restrictive State immunity ought to be followed instead of absolute immunity." (ibid.: 114). As both authors show in their paper, this interpretation of the case by Mikelènas was far from obvious.
} 
Evaluating this historical example, a conclusion can be drawn that the Supreme Court of the Republic of Lithuania demarcated itself from the political tensions exactly by refusing (or at least being reluctant) to perform its genuinely un-jurisdictional legislative function, by an attempt, at most, to somehow modify, but not overthrow the existing law (i.e. the old Code), and not to change headlong the formed legal practice after the new Code came into force with the aforementioned gap (what could be even considered as holding to the principle of stare decisis). The Supreme Court should be held in esteem here for sticking to the ethics of restrained adjudication.

\section{THE ETHICS OF RESTRAINED ADJUDICATION}

We should start from the acknowledgement that the reaction to the propaganda of the judicial activism by democratic, anti-interpretativist or antiactivist radicalism is very useful for the pro-activists. In this respect Scalia's approach should still be regarded as an example of this kind of radicalism. It is not enough to slightly modify the emphasis on the requirements of democracy by some rather artificial concession to the common-law tradition by alleging that it "should [not] be scraped away as a barnacle on the hull of democracy, ${ }^{\prime 32}$ although probably not continued to develop in the contemporary democratic world. We could ask, why then not abandon all common law tradition, i.e. all which is already created by this tradition. Doesn't strict scientific sense require that? Is it not simply undemocratic in its entirety?

The point is that we should deviate (or, more precisely, prepare a deviation) from democratic radicalism at a more general ideological level if we wish to institute properly founded alternative to the pro-activist position, and not get involved in a futile fluctuation between anti-activism and pro-activism, which is situated in the realm of pure/scientific reason in its entirety. The change concerns the whole mode of thinking/reason in Kantian terms. We should start from a very general statement that, instead of talking about some absolute/scientific rules of "democratic" adjudication, we should start talking about the ethics of adjudication that should be the ethics of restraint, but not activism. Judicial activism should not be encouraged in the democratic form of government, and the creation of law in courts should only be in an instance of uttermost exception. Holding to the ethics of restrained adjudication should be the rule of the internal point of view of judges/courts in the Hartian sense, tightly related (or even considered as a part) to the mostly general rule of recognition of our political-legal framework/design (the Hartian secondary

\footnotetext{
32 Antonin Scalia, supra note 17: 12.
} 
rules) ${ }^{33}$ as it is, i.e. with people's sovereignty and the limits to the separated powers. ${ }^{34}$ And that is also an essential and necessary prerequisite of the existence and survival of the legal system itself.

As already mentioned, the proper reaction to the problem of judicial activism should be in the change of the modes of reason in the Kantian sense in the corresponding academic discourse. In some sense, the battle between pro-activist and anti-activist camp is rather firmly settled in the field of pure reason in the Kantian sense. Pro-activists emphasize the impossibility of absolute (that of a scientific kind) correspondence of language and reality, absolute and unchangeable transference of the meaning by written word from one mind (that of a legislator) to the other mind (that of a judge); and then make the conclusion that thus the way for the creative jurisprudence is paved. The other camp - anti-activists - becomes entangled in democratic radicalism and talks about the possibility of creating some science of legal interpretation that makes the creation of law in courts impossible. Both of these camps continue in one or another way to be embedded in a wider range of logocentric ideological influences. Anti-activism continues the direct influence of logocentrism by the presupposition of the possibility of pure a-political court practice (in the line of the Kelsenian separation the inside world of law and the outside world of politics, facts, and ethics). Pro-activism is in the line with the realist modern (or even nihilist post-modern) reaction to the failures of the adaptation of logocentrism in law; juristenrecht is what is real as opposed to ideal, which, although it is to be disdained, must nevertheless be the place to begin. Despite that, it only shows that pro-activism is built/articulated on or through the opposition to logocentrism; it is constructed on the same ideological level and thus is indirectly influenced by logocentrism. Sometimes it even looks like pro-activism imputes/creates the thesis of the absolute correspondence of legal text and reality (when nobody alleges that) as the basis for the critical articulation of pro-activist ideology; speaking more metaphorically, "an enemy is rather created, and not real", but the creation of the enemy has its proper function - to form the starting point/basis for the advancement of the pro-activist ideology.

The point is that the problem, articulated either by anti-activists or proactivists, is that of a very fundamental level as concerns the margins of the field of

\footnotetext{
${ }^{33}$ Apart from the rule of the recognition itself, the rules of change (legislation) and rules of adjudication are considered by Hart as secondary rules.

${ }^{34}$ H.L.A. Hart, The Concept of Law, $2^{\text {nd }}$ edition (Oxford: Oxford University Press, 1994), p. 100-117. It should be born in mind that although this rule (i.e. holding to the ethics of restrained adjudication) should be rule of the internal point of view of judges, it should not be regarded as simple respect to secondary rules as rules by courts and other officials, but should be understood by judges/courts as "a public, common standard of correct judicial decision, and not as something with each judge merely obeys for his part only. Individual courts of the system though they may, on occasion, deviate from these rules [i.e. secondary rules] must, in general, be critically concerned with such deviations as lapses from standards, which are essentially common and public" (ibid., p. 115-116). The last sentence of the extract hits most exactly to the therein developed conception of the ethics of restrained adjudication.
} 
law, where the field of law "meets" the field of politics. At this level, law is generally a historically determinate (bearing in mind its origins in the Enlightenment) holistic totality, with the rule of law, human rights, writteness of constitutions, modern democracy, and separation of powers. This totality should not be understood in strict scientific terms. As H.L.A. Hart would suggest, the statement that law should be positive itself is a moral statement. Accordingly, taking something from the post-Popperian understanding of science - this holistic totality is really a design/project/experiment - we should conceive this design as a moral project. We should change all modes of thinking/reason from the Kantian pure to the practical one. ${ }^{35}$ We should also combine this understanding with the conception that law is generally also a humanistic project, as discussed above. It is the project in human/people and for human/people, and that is in line with the Hartian internal aspect of law - we should start from some, although common to all, imperatives inside us. This change and, together, the combination of conceptions should allow a more adequate ideological articulation of what is at stake in the quarrel of proactivists and anti-activists - the guidelines for the process of adjudication in our contemporary political framework. An instance of this more adequate ideological articulation should be precisely the application of the conception of the ethics of restrained adjudication, and that is reflected in two aspects that are going to be discussed further.

Firstly, some might say that if judges would abide by the ethics of restrained adjudication, law might become frozen and would be inadequately adapted to the changing values of its given society. But in the contemporary political configuration the general role for this kind of adaptation of law is prescribed to other institutions/mechanisms - parliament and people (if referendum is necessary). Today courts are not the institutions having the role of the dynamic/societal adaptation of law. Of course, as concerns the constitution, the process of this

35 In this respect Hans Paul Prüm offers an interesting perspective (Hans Paul Prüm, "Reducing Irrationality of Legal Methodology by Realistic Description of Interpretative Tools and Teaching the Causes of Irrationality of Legal Education," Jurisprudencija 1 (115) (2009)). He clearly points that "application of law ... depends on analytical-logical as well as on voluntaristic (willful) elements" (ibid.: 203), and the latter aspect poses the real problem. However, the German tradition (not only the Soviet tradition with so-called mechanic interpretation of law!) of Auslegung (which does not correspond to interpretation) makes an attempt for the scientific (strictly logical/analytical/theoretically rationalistic) approach to the problem, when all possible answers to the posed legal problem should be extracted from the legal texts. In this respect the German tradition offers an example of anti-activist radicalism, which is based not so much on the ideology of democracy, but on the domination of logo-centrism/overscientificity/Kantian pure rationalism. As an alternative to this approach Prüm offers pragmatism, i.e. abandon "looking for eternal truth but just for viable proposals to improve the respective problematic situation" (ibid.: 208; relying on Richard Rorty, Wahrheit und Fortschritt (2000)), one of which is "to accept and to teach but not clad" and "to look for other ways to minimize the problem [of legal uncertainty]" (ibid.: 212). Namely in the same way the ethics of restrained adjudication is aimed at definitely not ignoring the problem of legal uncertainty/un-correspondence of legal text and real life (i.e. it accepts the skepticism, on which most of the ideology of pro-activism is build), and, after that, looking for another way to solve the problem - by changing the modes of reason without necessitating the other outcome of skepticism, i.e. pro-activist radicalism. 
adaptation is procedurally more difficult, and therefore constitutional adjudication as a matter of exception may take the form of this adaptation, but, again, that is only the matter of level, which should not, if we accept the aforementioned ethics, transgress the sphere of being an exception.

Speaking about the second aspect, we should return back to the relationship between reality and law as text: in fact, it is rather absurd to even question the notion that reality is more complex or contingent than the norms (as text) could cover, although this relationship is more complicated than this simple insight could present. The relationship between reality/nature and law(s) has been complicated already from the times of Hume, when he opened the gap between is and ought, with the further conclusion that law is essentially a human product ${ }^{36}$ (although reality/nature remains influential to the process of human productivity, as Hume's interpreter Popper would suggest by his conception of the inductive path of science $)^{37}$, and this production of law is intrinsically related to human linguistic and rationalistic capabilities.

In resonance with this we also have the notion that law is essentially a matter of language $^{38}$ - we may call the modern legal society with the rule of law, modern democracy and protection of human rights a linguistic/rationalistic project. And, as mentioned, it is also a humanistic project, in relationship to which the ethics of adjudication should require balancing democratic and liberalistic roles of courts - to apply the will of the people as presented in the legal text (democratic role) and to protect human if that will oversteps the boundaries, delineated by the universal human rights (liberalistic role). Most contemporary constitutions inscribe/textualise those rights, as well as basic secondary rules in the Hartian sense, and that is also a part of the aforementioned project of the modern legal society as being the linguistic one. They are written not in vain, although this writtenness (as Levinson uses this word) definitely does not solve all the problems "in the battle for the rule of law" (constitutional texts contain ambiguities, inconsistencies, gaps and the like) and itself could be conceived as an evidence of the skeptical approach while designing the project. ${ }^{39}$

Nevertheless, understanding the whole project at the level of practical reason still allows for a clear articulation of the roles of institutions and powers designed

\footnotetext{
36 And, as errare humanum est, contingency and, accordingly, complicacy comes from both sides reality and law. Not only reality is more complicated than the law as text is; the latter may be more or at least not less complicated (ambiguous, contradictory, etc.) than the reality is.

37 Karl Raimund Popper, The Logic of Scientific Discovery (New York, 1965), p. 276-278.

38 John Gibbons, "Language Constructing Law": 3; in: John Gibbons, ed., Language and the Law (London, New York: Longman, 1994).

39 Sanford Levinson, supra note 6: 376 ("The very existence of written constitutions with substantive limitations on future conduct is evidence of skepticism, if not outright pessimism, about the moral caliber of future citizens; else who not simply enjoin them to "be good" or "do what you think best"? Writers of constitutions must have a very high confidence in the ability of language both to "harden" and to control").
} 
therein. Accordingly, the role of a court, especially as a so-called "guardian of the constitution", is to preserve some fundamental norms, to fix some fundamental humanistic system of values for future generations not to change them so easily. The intensity of a law as projected against the contingency of reality/societal behavior is especially direct at the constitutional level, where it is still clear that even by writing the constitution men were not able to solve Rousseau's impossible task of putting the law above man. ${ }^{40}$ However, as alleged by Martin Loughlin, basing his thoughts on Alexis de Tocqueville, there is no better solution in this situation than to appoint this impossible task to judges. Judges, as having "certain habits of order, a taste for formalities, and a kind of instinctive regard for the regular connections of ideas, which naturally render them very hostile to the revolutionary spirit and unreflecting passions of the multitude, ${ }^{\prime 41}$ are best suited for this task of preserving fundamental, constitutionally inscribed values of our society, especially the human rights. But, as opposing "their aristocratic propensities to the nation's democratic instincts, ${ }^{\prime 42}$ judges should strive to preserve, not change them. That could only be achieved through the ethics of restrained adjudication, but not the anti-activist radicalism or pro-activist realistic/nihilistic resignation, when some "wish, that real life, with its contradictions and actualities, should conform to some a-priorical theoretical constructs", and others respond - "it does not correspond, so what? That is worse for the constructs." ${ }^{43}$

\section{CONCLUSIONS}

1. The American foundations of the power of judicial review and its corresponding development are based on intrinsic textualism, and are also far from being clear in relationship to the political neutrality of the process.

2. Even if the argumentation, based on the divergence between common-law and civil-law traditions, is used in the anti-activist camp in the civil-law countries, its weaknesses should be kept in mind (i.e. its being based on the authority of the tradition, the convergence of the traditions, and the practical familiarity with the stare decisis in the civil-law tradition), and also the fact that not everything from the common-law tradition is impractical and unuseful for the anti-activists (the conception of stare decisis itself).

3. The Lithuanian system should acquire a substantial element of the aristocratic form of the government, if the judicial precedent as the judicial creation of law and as an element of the legal system would be explicitly accepted.

\footnotetext{
${ }^{40}$ Martin Loughlin, The Idea of Public Law (New York: Oxford University Press, 2005), p. 115.

${ }^{41}$ Ibid., p. 129.

42 Ibid.

${ }^{43}$ Egidijus Kūris, supra note 9: 128.
} 
4. Constitution is the law that may have gaps, and there is no clear theory (including the Kelsenian one) that would require any court to usurp the power of filling them in by its doctrine.

5. The institution of the properly founded alternative to pro-activist position requires deviation from democratic radicalism, although at a more general ideological level - by changing the mode of thinking/reason in the Kantian terms from a pure to a practical one.

6. Holding to the ethics of restrained adjudication should be the rule of the internal point of view of judges/courts in the Hartian sense, tightly related to the mostly general rule of recognition of our political-legal framework/design as it is, i.e. with the people's sovereignty and limits to the separated powers.

7. The battle between the pro-activist and anti-activist camps is rather firmly settled in the domain of logocentric ideological influences.

8. There are gaps and inconsistencies in constitutions and laws; reality can be much more complex than the text of law presupposes. But neither of them prevents the ethics of restrained adjudication from starting to be a part of the internal view of any judge, and the conception of the legal system as linguistic-rationalistic and humanistic project only reaffirms the necessity of this beginning.

\section{BIBLIOGRAPHY}

1. Ambrasienè, Dangutè, and Solveiga Cirtautienè. "Teismo precedent reikšmè Lietuvos teismu praktikoje (The Role of Judicial Precedent in the Court Practice of Lithuania)." Jurisprudencija 2 (116) (2009): 61-78.

2. Berkmanas, Tomas. "Teismo aktyvumo kuriant ir aiškinant teisę plètros tencencija, motyvai ir problemos (Tendency, Motives and Issues of the Expansion of Judicial Activism in the Creation and Interpretation of Law)." Teisés problemos 2 (44) (2004): 30-47.

3. Dyzenhaus, David. Legality and Legitimacy: Carl Schmitt, Hans Kelsen and Hermann Heller in Weimar. Oxford: Oxford University Press, 2003.

4. Fletcher, George P. Basic Concepts of Legal Thought. New York, Oxford: Oxford University Press, 1996.

5. Gibbons, John. "Language Constructing Law": 3-10. In: John Gibbons, ed. Language and the Law. London, New York: Longman, 1994.

6. Glendon, Mary Ann. "Comment": 95-114. In: A Matter of Interpretation: Federal Courts and the Law. Princeton, New Jersey: Princeton University Press, 1998. 
7. Hart, H.L.A. The Concept of Law. $2^{\text {nd }}$ edition. Oxford: Oxford University Press, 1994.

8. Jankauskas, Kęstutis. "Adekvatus teisès principu aiškinimas konstitucineje jurisprudencijoje (Adequate Interpretation of Legal Principles in Constitutional Jurisprudence)." Teisés problemos 4 (46) (2004).

9. Jarašiūnas, Egidijus. "Konstitucinè justicija ir demokratija: keletas savveikos problemy (Constitutional Justice and Democracy: Some Problems of Interaction)." Jurisprudencija 64 (56) (2005): 74-83.

10. Jarašiūnas, Egidijus. "Oficialios konstitucinès doktrinos koregavimo problemos (The Problems of Correction of the Official Constitutional Doctrine)." Jurisprudencija 1 (115) (2009): 39-70.

11. Jokubauskas, Rytis. "Teisminio precedento privalomumo problema Lietuvos teisineje sistemoje (The Problem of Obligation of Judicial Precedent in the Lithuanian Legal System)." Jurisprudencija 5 (95) (2007): 51-56.

12. Kelsen, Hans. Grynoji teisès teorija (Pure Theory of Law). Vilnius: ALK, Eugrimas, 2002.

13. Kūris, Egidijus. "Konstitucija kaip teisè be spragu (The Constitution as Law without Gaps)." Jurisprudencija 12 (90) (2006): 7-14.

14. Kūris, Egidijus. "Konstitucinis Teismas ir istatymu leidyba: žvilgsnis "iš vidaus" (Constitutional Court and Legislation: View from "the Inside")." Teises problemos 1 (43) (2004): 115-132.

15. Lastauskienè, Giedrè. "Teisinio teksto interpretavimo ribu ir teisès principu santykis: teorinès nuostatos ir Lietuvos teismu praktika (Relationship between the Limits of the Interpretation of the Legal Text and the Legal Principles: Theoretical Approaches and Practice of Lithuanian Courts)." Teisès problemos 1 (47) (2005).

16. Lastauskienè, Giedrè. "Teisinio teksto tyrimo metodologija: teisès normu nustatymas (The Methodology of the Investigation of the Legal Text: Identification of Legal Norms)." Teise 56 (2005): 1-10.

17. Lastauskienè, Giedrè. "Turiningasis teisinio teksto aiškinimas - panaceja ar pavojus? (The Thoughtful Disquisition of Legal Text - Panacea or Risk?)." Jurisprudencija 8 (86) (2006): 63-70.

18. Loughlin, Martin. The Idea of Public Law. New York: Oxford University Press, 2005.

19. Mesonis, Gediminas. "Kai kurie Konstitucijos interpretavimo aspektai: expressis verbis ribos (Some Aspects of Interpretation of the Constitution: the Limits of the Expressis Verbis)." Jurisprudencija 5 (107) (2008): 19-27. 
20. Mesonis, Gediminas. "Keli konstitucijos interpretavimo askeptai: vertybiniu (moraliniu) argument galimybe ir ribos (Some Aspects of the Interpretation of the Constitution: the Possibility and Limits of Valuable (Moral) Arguments)." Jurisprudencija 2 (116) (2009): 45-59.

21. Mikelènas, Valentinas. "Interpretacinis žaismas, arba kaip kurti teisę be parlamento (Interpretation Game or How to Make Law without Parliament)." Jurisprudencija 2 (116) (2009): 79-92.

22. Mikelènienè, Dalia, and Valentinas Mikelènas. Teismo procesas: teisès aiškinimo ir taikymo aspektai (Judicial Process: Aspects of Legal Interpretation and Application of Law). Vilnius: Justitia, 1999.

23. On the Qualification Requirements of Higher Education in Law for the Persons Who Wish to Hold, under Procedure Established by Laws, the Position of a Judge. Ruling of the Constitutional Court of the Republic Lithuania. Official Gazette, 2008, no. 23-852.

24. Popper, Karl Raimund. The Logic of Scientific Discovery. New York, 1965.

25. Prüm, Hans Paul. "Reducing Irrationality of Legal Methodology by Realistic Description of Interpretative Tools and Teaching the Causes of Irrationality of Legal Education." Jurisprudencija 1 (115) (2009): 199-219.

26. Ragauskas, Petras. "Konstitucinio teismo vaidmuo istatymu leidyboje (The Role of the Constitutional Court in the Process of Legislation)." Teises problemos 1 (43) (2004): 8-54.

27. Scalia, Antonin. "Common-Law Courts in a Civil-Law System: The Role of United States Federal Courts in Interpreting the Constitution and Laws": 7. In: A Matter of Interpretation: Federal Courts and the Law. Princeton, New Jersey: Princeton University Press, 1998.

28. Schmitt, Carl. Political Theology: Four Chapters on the Concept of Sovereignty. Chicago and London: The University of Chicago Press, 2005.

29. Šileikis, Egidijus. "Aktyvistinè konstitucinè justicija kaip subtili diskecija inspiruoti teisinius modelius (Active Constitutional Jurisprudence as a Method to Influence Legal Issues)." Jurisprudencija 12 (90) (2006): 51-60.

30. Šimašius, Remigijus. "Teisès aiškinimas ir jo privalomumas (On Mandatory Interpretation of Law)." Teisés problemos 2 (44) (2004): 8-29.

31. Sinkevičius, Vytautas. "Konstitucijos interpretavimo principai ir ribos (The Principles and Limits of Interpretation of Constituion)." Jurisprudencija 67 (59) (2005): 7-19.

32. Smaliukas, Andrius, and Yvonne Goldammer. "The Restrictive Theory of State Immunity in Lithuania: Reality or Illusion." Baltic Yearbook of International Law 5 (2005): 111-132. 
33. Spruogis, Ernestas. "Teisès aiškinimo probleminiai aspektai (Problemic Aspects of Legal Interpretation)." Jurisprudencija 8 (86) (2006): 56-62.

34. Vaišvila, Alfonsas. "Teisès aiškinimas kaip teisès atpažinimas istatymu tekstuose (Legal Interpretation as Identification of Law in the Texts of Statutes)." Jurisprudencija 8 (86) (2006): 7-17. 